\title{
Using Self-Learning E-Book Modules for Geography Education Student on Geographic Information System
}

\author{
Anang Widhi Nirwansyah \\ Institute of Geography, University of Cologne \\ Cologne, Germany \\ Universitas Muhammadiyah Purwokerto \\ a.nirwansyah@smail.uni-koeln.de \\ (Corresponding author)
}

\author{
Sakinah Fathrunnadi Shalihati \\ Geography Education Department \\ Universitas Muhammadiyah Purwokerto \\ Banyumas, Central Java
}

\begin{abstract}
This article is focused on the implementation of e-book modules on Geographic Information System (GIS) in university student. The effectiveness of this module is measured through several actors and collectively investigated by questionnaire and analyzed by quantitative descriptive analysis. This research finds that students feels that there is improvement on they're learning process and enhance self-learning capacity due to autonomous instruction inside the module. Teachers respectively understand and cooperate with the learning process and inputs several points in the module implementation. Several critics from instructional media expert also expand the module for optimum usage in the learning process.
\end{abstract}

\section{Keywords-component; Self-learning; E-book; Modules; Geographic Information System}

\section{I.INTRODUCTION}

Geography has been promoted as main subject Indonesia's high school. In lower level, geography substances also introduces elementary school student to physical, social and environmental phenomena on earth surface. Maps, globe, satellite imageries, and Geographic Information System (GIS) are taken to provoke students for better understanding about the world and its interaction. In many countries, GIS has been conceded as main supportive tool in geography didactic [1-2]. Meanwhile, Indonesia was started to introduce GIS theory in 1994 curriculum. GIS encourage teacher and being principal substance that agreed by Indonesia Geographer Association in 2017 [3]. This agreement is understood as GIS role in the science of geography, theoretically and in various applications. The appearance of GIS in the national curriculum, especially at the senior high school level, shows that the importance of GIS has been concerned not only by pedagogic geographers, but also curriculum developers [4]. Moreover, GIS integrates the core of science in geography and builds soft skill especially in university level.

Geography teaching in school practically is taught by geography teacher who studied in didactic program. This program basically involves GIS in main course together with remote sensing. This enthusiastic subject gives more experiences to students in understanding concept and its practices, especially presuming that they have GIS laboratory with its high-end computer hardware. Meanwhile, when GIS implementation is acquired in schools. GIS is struggling withits complicated theoretical concept with low skill of teacher in implementation, while the infrastructure constraint remain GIS as major issue for schools [5]. Donaldson found that among 750 high schools in Ohio, only $3 \%$ of teachers have used GIS in their teaching [6].

Student in geography education principally understands about GIS skill importance in spatial data processing, including the application in classroom teaching. GIS can be used as a learning material as well as a medium of learning, which can be used as a tool for teaching, learning and educational tools (both as tools and tutorial materials) that are interactive, interesting, and challenging (from school age to adults) of the ideas or concepts of location, space (spatial), demographics and geographic elements on the surface of the earth along with the associated attribute data attached to it [7]. Improvement of can be implemented through curricula. GIS in the school teaching needs comprehensive planning and detailed strategy [8]. Theoretical concept of GIS dominantly actualizes teaching processes as material in geography in many schools. But, students have less experience in real practical application, or even seen GIS software.

This article is written in progress of GIS implementation in bachelor degree student in Universitas Muhammadiyah Purwokerto, Banyumas, Indonesia. This research is issued as local finding where most of high school teacher in Banyumas express their difficulties in transferring GIS as one of subject material in their school. Moreover, spatial skill through map using demonstration sometimes also creates problem where lack of media remains the major issue. Elementary geography has been restricted to cognitive skill including memorize the names of states and their capitals, recite definitions of landforms, or color lines to represent locations [9]. In this research, we try to improve bachelor student in geography education to understand comprehensively GIS application. This object of this research is generated from students of UMP 
who are taking course application of GIS in their second years. This course purposes students to have ability to solve problem in their expertise, based on results of information and spatial data analysis [9]. E-module is believed as educational tool to overcome the lack of material where students initially cannot optimize their practical experience. The importance of module which is contextually related with educational research and the subject will improves better understanding of fact in data collection, basic concept from literature reviews, procedure and principal content in learning material [10]. This research believes that easy access and free access of GIS prepared module in the Internet leads to self-learning capacity of student. This experience also triggers the student to interact more with this technology, which can be implemented for school in the near future.

\section{RESEARCH METHODS}

\section{A. Location and Participant}

This research is conducted in geography education department, faculty of education, Universitas Muhammadiyah Purwokerto during November 2016-April 2017. This research starts with preparation, action and final. We prepare the ebook for subject Application of GIS. This module is written based on 4D model that started from define, design, develop and disseminate. Feasibility test of this e-module is established during pre-teaching process and limited test also designed to obtained suitable draft. In this research, several actors involve during the implementation of e-module. Students who join the subject are measured; lecturers as facilitator also give proportional notice. Instructional media expert also gives valuable remarks for the e-book draft (see table 1).

\section{TABLE I. ROLE OF ACTORS IN MODULE EVALUATION}

\begin{tabular}{|l|l|l|}
\hline \multicolumn{1}{|c|}{ Actor } & \multicolumn{1}{|c|}{$\begin{array}{c}\text { Role in module } \\
\text { evaluation }\end{array}$} & $\begin{array}{c}\text { Min } \\
\text { Score/Max. } \\
\text { Score }\end{array}$ \\
\hline $\begin{array}{l}\text { Lecturer/team } \\
\text { teaching }\end{array}$ & $\begin{array}{l}\text { Self-instruction remarks, } \\
\text { contain, module } \\
\text { structure, writing } \\
\text { technics, and user- } \\
\text { friendly aspect. }\end{array}$ & $35 / 140$ \\
\hline $\begin{array}{l}\text { Instructional } \\
\text { media expert }\end{array}$ & $\begin{array}{l}\text { Attractiveness and } \\
\text { organizational aspect, } \\
\text { fonts and its size, space, } \\
\text { and writing consistency. }\end{array}$ & $25 / 100$ \\
\hline Students & $\begin{array}{l}\text { Content, and } \\
\text { implementation. }\end{array}$ & $0 / 34$ \\
\hline
\end{tabular}

Descriptive analysis is beneficially used in this research when deals with quantitative data collected from questionnaire. Questionnaire A (instructional media expert remarks); $\mathrm{B}$ (validation paper from GIS teacher); and C (response information from students) are collected on behalf to investigate the e-module effectiveness. Binary score yes $=1$ and no $=0$ is utilized to obtain rapid data and avoid uncertainties. The e-module itself is previously uploaded in the E-Learning, which called On-class UMP (see fig. 1) and accessed by students through their matriculation number. Interview is also conducted in from several actors to gain information and data during research. This step is taken to overview the e-book utilizing by student and teacher. Some difficulties on practicing GIS especially on ArcGIS software application in particular situation also noticed, but assistance activity among student also positively understood as classroom dynamics.

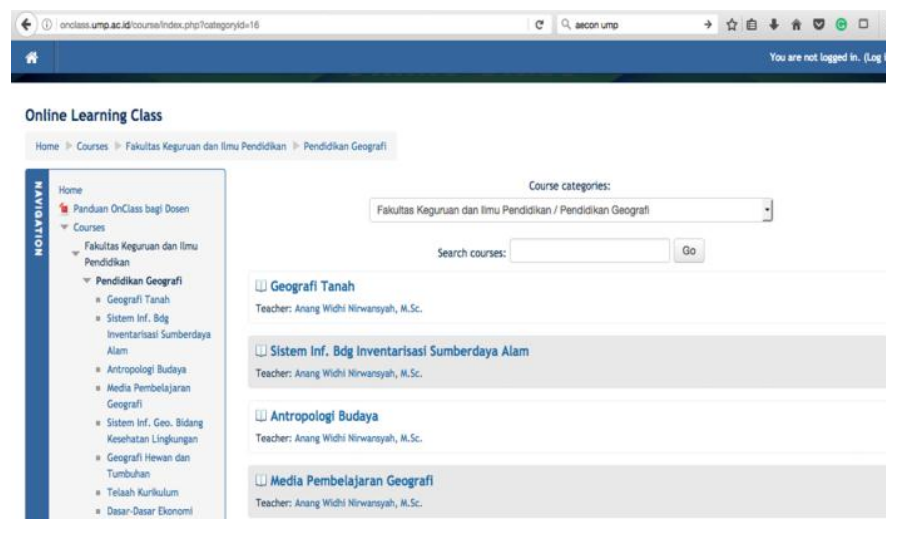

\section{B. Landuse Direction Analysis As Learning Activity}

Topic of land use direction analysis is promoted as one of topic in this e-book module. It contains basic information of using GIS in fundamental spatial planning where technical skill also gathered through overlay and scoring processes. Arsyad [11] also Agriculture Department [12] commits this basic analysis to evaluate the potential land use by using several thematic maps, namely: soil map, slope map and rainfall map. In this research, students independently using GIS laboratory and access their online learning platform and download the e-book. This e-book contains instruction, data, and analytical question that conform students to do several works including georeference, digitize, and create tabular information for quantitative analysis. Scoring and overlay as major processing lead the students to understand a little bit of logical expression in "if" and "then" formula. While basic function of "sum" and "or" also present in this guiding e-book.

This e-book controls student-learning activities, and specifically measures their performance during the process. This module is conducted for four week learning activities. In very first week practically, students remain sitting in the laboratory once a week as it is scheduled before. Then, teacher will involve opening the class and giving framework of particular learning activities. Some short theoretical concept also given during first meeting and discussion related with the particular analysis is organized in groups. In that week also students will regulate themselves in ArcGIS basic functions in vector data creation, and its procedural requirements. Raw data are accessible in the online platform and downloadable using laboratory computer, or their own drives. Second week, Student will start to do their works individually and discuss some particular problems with the assistance that initiated from senior student. And during 120 minutes this self-learning 
process actively done by student and ended when time is up. Started with collecting data and inputs coordinate $(\mathrm{x}, \mathrm{y})$ and involving projection on the following process. Particularly, we use Pekalongan data analysis as part of our previous research [13-14]. Digitizing process will be started as soon as students finished the georeference step precisely. The third week, students confront with numeric data which in tabular view and try to express the thematic maps into several categories. And this will results thematic maps with area color symbol. Scoring and overlay process of these maps will negotiate student in analytical situation where their basic mathematical ability is needed. Finally, these three thematic maps will produce one land-direction maps that students can identify their own works through their monitor. The final week, every group will create layouts from their works and design scientific poster as to be presented. In that moment, questionnaire has been distributed and remarks of the module were collected.

\section{RESULTS AND DISCUSSION}

\section{A. Teachers' Perspective}

Although small intervention on ArcGIS installation is gathered due to several failures of computer unit in laboratory, the process indicates that students who have started to learn GIS are enthusiastic and active. Teacher is overwhelmed with several basic question regarding the process and tasks for next several weeks. In the beginning, students get to access their own online learning with their ID, and it takes a while due to internet connectivity. Then after, the learning activity begins and students start to work individually (see fig. 2).

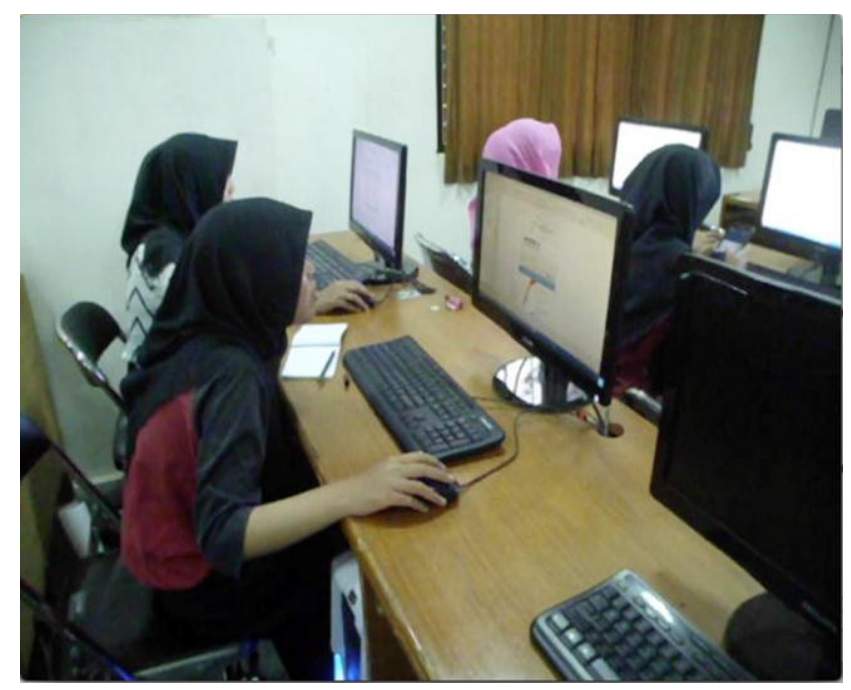

FIG. 2 SELF-LEARNING PROCESS USING E-BOOK MODULE IN COMPUTER LABORATORY

Teachers' knowledge and skill on GIS are actually profound through academic experience during their college, which is from geography education background. Moreover, several training and also research experiences have improve their capacity, not only operating but also mentoring in basic ad medium level. This e-book module actually has already prepared a year before then continuously being evaluated in the learning process. In this research, teacher examines this material before the class and inputs related with the writing and its structure. But, when teachers are reviewing the classroom activity during the module implementation, they said that students are actively welcoming and performing autonomous and cooperative learning among others.

"...This e-book is very informative with pictures and complete technical guidance. A minor critic in the writing which may contains grammatical error in Bahasa Indonesia pattern". (L.1)

Currently, several remarks are gathered in this research including self-instruction remark has 63/96 points as mentioned that persuade instruction has written generally in the e-book, but in several some sentences still neutral and tends to be unordered. While module content aspect collects $10 / 12$ as contain of this e-book is strongly related with the previous research that has been done for the last 2 years and serves simple method and easy command. In this research also mentioned that module structure gains $5 / 8$. This mark shows that structure of the module is one of the issues when proper design of module should be related with its level of difficulties, which might still improperly structured. Writing technique aqcuires14/16 and very well written with easy language without neglecting scientific context, and userfriendly aspect gets 6/8 where design and pictures are clear and understandable. All of these components (see fig. 3) Implies a total remarks from teacher perspective by $98 / 140$ or $70 \%$ of maximum evaluative score.

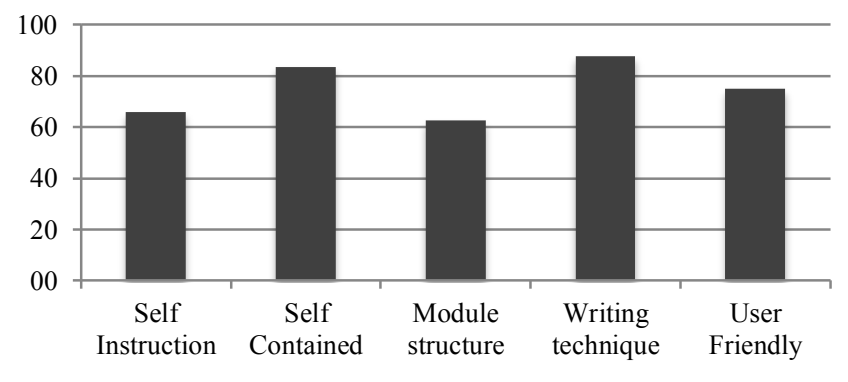

FIG. 3 TEACHER REMARKS FOR EACH COMPONENT OF THE EBOOK

\section{B. Instructional Media Expert}

It always be respectively positive inputs from experts who expecting perfection in student module. Valuable information and critics can be taken as evaluation during the review. This research shows that reviewer gives 27/36 score for attractiveness of the module, as it is comprised with the front cover and associated pictures inside. In the other aspect, reviewer concerns about the paragraph and gives input in size of margins. Furthermore, about 12/16 is given to font and its size feature include size of tittle, sub title and paragraph content which still needs adjust into standards. Space aspect draws $13 / 20$ points, which related with spacing format, and consistency clarify $23 / 28$ points including the stability on format, fonts and writing structure. Overall, the performance of this e-book modules reaches $75 \%$ and negotiable for future improvement. 


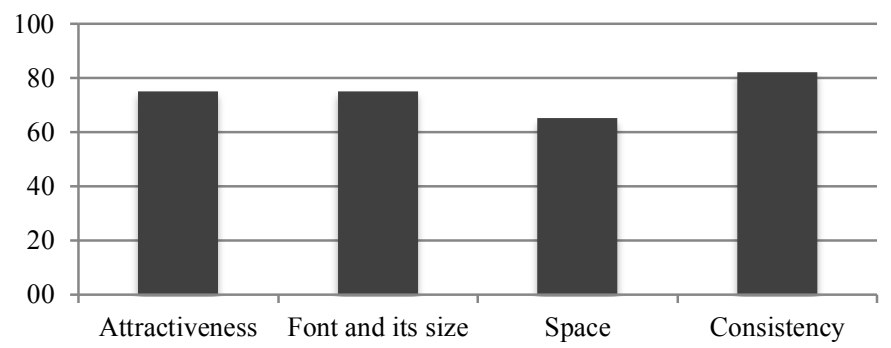

FIG. 4 E-BOOK MODULE PERFORMANCE BASED ON INSTRUCTIONAL MEDIA EXPERT REVIEW

\section{Challenge for Students}

Students undertake important process in this research. Most of them reveal their own understanding in the subject and task given. Continually, from the beginning individual and cooperative activities increases and results positively until furthermost part. Through the questionnaire, this research finds that most students assuredly that his learning process are improved through the e-book. Self-instruction in the modules tends to be opened the question and release their cognitive in GIS process. This beneficial steps on learning can remarkably useful for student to understand more, not only theoretical concept but also how to operate and manage spatial data in GIS software environment. While the students showed gradual progress on gaining geographic content knowledge, the overall improvement on their map skills was rather rapid and sporadic [1]. Finally, some students give corrective inputs for this modules but other give positive feedback for the process.

“...In the Application of GIS course, I feel more fun but also need patience and details so then can make us more understand and competence in learning GIS application". (S.4)

“...I still need a guidance from teacher, because I feel need extra time to understand the instruction. And also, each student have different understanding". (S.25)

Different perception of the instruction probably cannot be denial as every student has its own capacity and understanding. But, here we notice that student finally can handle the situation and encourage themselves into discussion with their friends, senior or even asking directly to their teacher, something that might not happened before. Overall this module takes $92,05 \%$ for its performance due to students' evaluative reports, where content comes into $91,80 \%$ and the implementation records $92,29 \%$.

\section{Discussion}

This research might confronts real situation in the public school. Facilities, and IT infrastructure is always be mentioned as major issue for teacher. But meanwhile, in university we always receive groups of high school student who organized by their teacher asking for short course on basic GIS including its tutorial on GIS software. So, it seems not only infrastructure which actually every public school, not all-are equipped with computer laboratory which can be accessed by students easily. Dealing with the software difficulties, there always be an alternative to solve this matter, including the Opensource software that can be downloaded in the internet and doesn't require a lot of budget. So, nowadays learning GIS is better and easier than 10 years ago. As mentioned [8] that teachers probably do not have the skills or knowledge to prepare students to access a rich map resources without consider GIS as fundamental tools. With this situation, students will not fully understand geography unless it's definition and concept.

Through the years, books specialized for geography teachers have been dominant on practice and have reflected the content and pedagogies of their periods [15]. Related to this, in national level, geographer association promotes some obligatory components that contain 10 elements of geography teaching including GIS. This purposed idea is manufactured to overcome the global changing in regional of the nations and the technology improvement that implies to geography itself. This situation challenges every student which purpose to be teacher to comprehensively understand the core of geography and the application spatial data processing with GIS. This on going research conducts correlative approach in relating the use of e-book module with students' achievement. While, in this article some beneficial findings related in terms of teacher and student reflection, which may different in some cases. Teachers actually aware about the textual forms of the e-book that efficiently needs to be logical in writing, structure, and minimize in minor error. These might be involved repetition, word selection, and instruction ambiguity, which may occur in the module. In the other hands, students are relatively using this module as personal guidance of learning process and give them huge opportunity to access additional source and discuss in the various ways including with social media. Valuable inputs from instructional media experts in pointing organizational aspect of the modules where should be standardized. This idea is related with the potential improving of this module to be more accessible for others and expand its form into book, or book chapter. Theoretical concepts, and references also another aspect that prospectively can be handled to optimize results.

\section{E. Conclusion}

This research concludes that e-book module gain positive impact in learning process of Geographic Information System (GIS) for students, which increase self-learning activities of student. Teachers also realize that the usage of research-based module enhances the understanding of student on how to deal with spatial data and its process for research and also for teaching.

\section{Acknowledgement}

This article is written as part of educational research funded by LPPM UMP through Junior Lecturer Grants with contract number A-11.III/624-S.Pj./LPPM/XI/2016.

\section{References}

[1] E.-K. Shin, Using Geographic Information System (GIS) to Improve Fourth Graders' Geographica Content 
Knowledge and Map Skills. Journal of Geography, 105 (2006) $109-120$. https://doi.org/10.1080/00221340608978672.

[2] J. J. Kerski, The Implementation and Effectiveness of Geographic Information Systems Technology and Methods in Secondary Education. Journal of Geography, 102 (2003) 128-137. https://doi.org/10.1080/00221340308978534.

[3] IGI, Rumusan Hasil Workshop Ikatan Geograf Indonesia Tahun 2017 (Yogyakarta, Indonesia, 2017).

[4] C.-C. Lam, E. Lai, \& J. Wong, Implementation of geographic information system (GIS) in secondary geography curriculum in Hong Kong: current situations and future directions. International Research in Geographical and Environmental Education, 18 (2009) 57-74. https://doi.org/10.1080/10382040802591555.

[5] I. Setiawan, Kontribusi SIG dalam Meningkatkan Kualitas Pembelajaran Geografi di Sekolah Menengah. Semin. Nas. Pendayagunaan Inf. Geospatial untuk Optim. Oton. Drh. (Surakarta: UMS Press, 2013), pp. 219-223.

[6] D. Donaldson, Public high schools' ability to support GIS: An Ohio case study. Geographical Bulletin - Gamma Theta Upsilon, 41 (1999) 91-102.

[7] E. Prahasta, Konsep-Konsep Dasar SIG, 1st ed (Bandung: Informatika, 2002).

[8] S. W. Bednarz, Geographic Information Systems: A Tool to Support Geography and Environmental Education? GeoJournal, 60 (2004) 191-199. https://doi.org/10.1023/B:GEJO.0000033574.44345.c9.

[9] J. Stallworth, Corsandra; Braun, Joseph A, GIS Programs:Geography Tools for Teachers and Students. Social Education, (2000) 161-164. http://www.socialstudies.org/sites/default/files/publication s/se/6403/640307.html (accessed July 16, 2017).

[10] E. Parmin; Peniati, Jurnal Pendidikan IPA Indonesia. Jurnal Pendidikan IPA Indonesia, 2 (2012) 203-208. https://doi.org/10.15294/jpii.v4i2.4179.

[11] S. Arsyad, Konservasi Tanah Dan Air. (2011) 1-19.

[12] Kementrian Pertanian, SK MENTAN No. 837/Kpts/Um/11/ 1980 tentang Kriteria dan Tata Cara Penetapan Hutan Lindung (Indonesia: Department of Agriculture of Indonesia, 1980).

[13] A. W. Nirwansyah, Komparasi Teknik Ordinary Kriging Dan Spline Dalam Pembentukan Dem ( Studi Data Titik Tinggi Kota Pekalongan Provinsi Jawa Tengah ). IV (2015).

[14] A. W. Nirwansyah, Implementation of Community Based Disaster Risk Reduction ( Case Study: MangroveCommunity. III (2014) 127-141.

[15] D. Kent, Ashley; Rawling, Eleanor; Morgan, John; Naish, Michael; Roberts, Margaret; Bennetts, Trevor; Balderstone, David; Battersby, Jeff; Lambert, David; Leat, David; Hassell, Teaching Geography in Secondary Schools: A Reader, 2nd ed (London: Taylor and Francis e-Library, 2002). 